Article

\title{
Eight Tons of Material Footprint-Suggestion for a Resource Cap for Household Consumption in Finland
}

\author{
Michael Lettenmeier ${ }^{1,2,6, *}$, Christa Liedtke ${ }^{1,3}$ and Holger Rohn ${ }^{1,4,5}$ \\ 1 Wuppertal Institute for Climate, Environment and Energy, Döppersberg 19, Wuppertal 42103, \\ Germany; E-Mails: christa.liedtke@wupperinst.org (C.L.); holger.rohn@wupperinst.org (H.R.) \\ D-mat Ltd., Purokatu 34, Lahti 15200, Finland \\ 3 Folkwang University of the Arts, Industrial Design, Klemensborn 39, Essen 45239, Germany \\ 4 Faktor 10-Institut für nachhaltiges Wirtschaften gemeinnützige $\mathrm{GmbH}$, Alte Bahnhofstraße 13, \\ Friedberg 61169, Germany; E-Mail: holger.rohn@f10-institut.org \\ 5 Institute of Refrigerating and Biotechnology Lomonosov, ITMO University, Ulitsa 9, \\ St. Petersburg 191002, Russia \\ 6 Department of Design, Aalto University, Hämeentie 135 C, Helsinki 00760, Finland \\ * Author to whom correspondence should be addressed: E-Mail: michael@d-mat.fi; \\ michael.lettenmeier@wupperinst.org; Tel.: +358-405-412-876.
}

Received: 8 June 2013; in revised form: 3 February 2014 / Accepted: 23 June 2014 / Published: 9 July 2014

\begin{abstract}
The paper suggests a sustainable material footprint of eight tons, per person, in a year as a resource cap target for household consumption in Finland. This means an $80 \%$ (factor 5) reduction from the present Finnish average. The material footprint is used as a synonym to the Total Material Requirement (TMR) calculated for products and activities. The paper suggests how to allocate the sustainable material footprint to different consumption components on the basis of earlier household studies, as well as other studies, on the material intensity of products, services, and infrastructures. It analyzes requirements, opportunities, and challenges for future developments in technology and lifestyle, also taking into account that future lifestyles are supposed to show a high degree of diversity. The targets and approaches are discussed for the consumption components of nutrition, housing, household goods, mobility, leisure activities, and other purposes. The paper states that a sustainable level of natural resource use by households is achievable and it can be roughly allocated to different consumption components in order to illustrate the need for a change in lifestyles. While the absolute material footprint of all the consumption components will have to decrease, the relative share of nutrition, the most basic human
\end{abstract}


need, in the total material footprint is expected to rise, whereas much smaller shares than at present are proposed for housing and especially mobility. For reducing material resource use to the sustainable level suggested, both social innovations, and technological developments are required.

Keywords: consumption; lifestyle; household; natural resources; resource cap; sustainability; transition; material footprint; MIPS; ecological backpack

\section{Introduction}

An increasing number of consumers, especially in Western societies, can be characterized by a medium or high resource consumption profile. Since these lifestyles are becoming more popular in growing cities worldwide, resource efficiency is an issue of increasing importance on different levels.

The use of natural resources by human activities has been constantly growing during the recent decades. From 1980 to 2008, for example, the extraction and use of many raw materials on a global scale has grown by tens or hundreds of percent. Since 2000, the global resource extraction has risen further and with a stronger growth rate than in the previous decade [1]. The Total Material Consumption (TMC) of between 40 and 50 tons per capita in a year [2] for most industrialized countries is factor four to five higher than the sustainable level suggested by Bringezu [3]. In addition, the "ecological footprint", i.e., the land area required for human activites either directly or for absorbing the carbon dioxide emitted, has doubled since 1966. It has exceeded the productive land area available already during the 1970s, from 2008 on by more than 50 percent [4]. Other studies focus on the limited environmental space and the effect of exceeding limits on, e.g., biodiversity, climate change, clean water, erosion, soil degradation, migration, social conflicts due to limited acces to resources, etc. [5-9].

The welfare and the consumption of households are the ultimate purpose of basically any economic activities [10]. The amount of household consumption is still growing on a global level [11]. Thus, the way households are living and consuming is a major basic driver of the overconsumption of natural resources by the human technosystem $[12,13]$. However, this does not mean that households were the only actors that can affect sustainable resource use. In order to decrease the resource use from household consumption, both production and consumption patterns have to be changed, as well as infrastructures and politics that are provided by governments.

The purpose of this paper is to explore the general possibilities of, and the basic prerequisites for, "sustainable lifestyles" [14] in terms of natural resource use. The hypothesis of this paper is that a sustainable level of natural resource use by households is achievable and it can be roughly allocated to different consumption components in order to illustrate the need for change in our lifestyles. The paper is mostly based on data from Finland. Therefore, the assumptions, comparisons, and conclusions especially relate to Finnish households, although they might be similar when studying other Western countries.

On the basis of results from macroeconomic calculations [2,3] we propose an amount of eight tons per person in a year for household consumption and two tons per person in a year for public 
consumption (e.g., education, health care, public administration). The indicator for describing the resource use by household consumption is the material footprint (see Section 2.3). On the basis of existing research on Finnish households and other research results, promising practices and examples, possible future material footprint levels are reasoned (Section 4). They can, on a more holistic basis than earlier benchmarking approaches (e.g., [15]), provide a benchmarking framework to which the material footprint of products and activities can be compared. However, it is noteworthy to mention that these are only suggestions because user behavior and social practices of households greatly vary (e.g., [16-18]) and technological development in the coming decades can hardly be anticipated $[19,20]$. Therefore, Section 4 shows only one possible profile of sustainable household consumption. Conclusions concerning the results and the ways to achieve them are given in Section 5 .

\section{Methodology}

This paper is based on several methodological approaches and decisions choosen for developing a reference framework to assess household consumption. It integrates an interdisciplinary and transdisciplinary, transition research oriented view for an action research approach that helps to reflect present resource use. Thus, it is intended to support the creation of new ways of low resources individual lifestyles. It, thus, refers to a variety of approaches of transition and action orientated research, such as [21-26]. The material footprint as a method for calculating the natural resource use of households is briefly described in Section 2.1. Section 2.2 describes in which way the system boundaries for households were set. Section 2.3 shows central assumptions for the study and its calculations, as well as how and which kind of existing research results, promising practice examples, and other aspects were utilized for suggesting a framework for sustainable resource use in household consumption.

\subsection{Material Footprint and Resource Efficiency Potential Calculations}

The term material footprint was established by Lettenmeier et al. [27] as a parallel term for the ecological backpack created by Schmidt-Bleek [28]. The intention was to apply the increasingly popular footprint metaphor for comprehensively illustrating and communicating resource use and material flows. The term material footprint has mostly been used to describe the life-cycle-wide resource use of products, services, activities, and households on micro level (e.g., [27,29]).

The material footprint as used in this paper is calculated by using the MIPS methodology (Material Input Per unit of Service). MIPS values are calculated by summing up the amount of natural material resources required throughout the life cycle in order to provide a specific benefit [27,28,30,31]. The material footprint, as used in this paper, sums up the MIPS categories abiotic and biotic recources, as well as the erosion out of the category soil movement in agriculture and forestry. The resource categories of water and air are not part of the material footprint and are, thus, left out of this study.

The material input contains both the resources used in human economy and the unused extraction (see [32]). This means that any material flows, regardless of their economic utility, are considered.

MIPS values are expressed in mass units per unit of the service provided, for instance in kilograms per kilometer traveled. The concept of service (S) in MIPS is based on the notion that any product is not an end in itself, but it is only produced to fulfill a specific service or need [28]. Thus, even very 
different products and services can be compared to each other on the basis of the service they provide (e.g., a video conference service and an aeroplane as means for meeting people located far away).

The calculation data used for this paper is mostly the same as in two Finnish research projects on the material footprint of households, "FIN-MIPS Household" [33] and "Basic income MIPS" [29].

The calculation and presentation of the results in Section 4 can be seen as a rough variation of the Resource Efficiency Potential Analysis (REPA) described by Rohn et al. [34]. The REPA analyses the resource efficiency potential of specific or new technologies, products and strategies in comparison to previous or average ones. In this paper, the comparison of the sustainable material footprint level to the existing level for both household consumption as a whole and the different consumption components can be interpreted as REPA on system and subsystem level.

In addition to defining the household as a system, system boundaries are also strongly influenced by the way of calculating the resource use of households. The material footprint, as a micro level approach, is calculated on the basis of the life-cycle material input of all goods and services used by the household (see [27,30]). In terms of natural resource categories, it is equivalent to the term Total Material Requirement (TMR), including abiotic and biotic material resources (including their unused extraction) and erosion in agriculture and forestry, which is the cumulative primary material requirement for the products and services consumed. However, the calculation procedures used here are different from the application of TMR (Total Material Requirement) and TMC (Total, Material Consumption, see [34]) on a macro level. Macro level calculations are usually based on data such as physical input-output tables and consumption expenditure, whereas the TMR (i.e., material footprint), used here, is based on life-cycle material flow calculations of products and activities.

One major difference between applying TMR as micro level material footprint in this paper and its application on most macro level studies concerns the allocation of the material flows of infrastructure like houses, roads, railways, etc. In the material footprint, as used here, the material inputs for the existing infrastructure stock, newly built infrastructure and infrastructure maintenance are allocated to the user of the infrastructure by dividing the life-cycle-wide material input required by the expected useful lifetime of the infrastructure (see [31,35,36]). In macroeconomic material flow accounting (MFA), inputs for constructing the infrastructure are usually allocated to the year they are used. Only the maintenance, use, and renewal of the infrastructure are allocated to the material flows of the years the infrastructure is in use. Thus, in countries with most of their transport infrastructure already built, this leads to considerably smaller values for mobility and transportation in macroeconomic TMR and TMC calculations. In addition, in these maroeconomic calculations, transport infrastructure is often allocated to public consumption so that its material inputs are not allocated to the households. Thus, macroeconomic material flow calculations for consumption (e.g., [2,37,38]) may provide significantly lower mobility-related values than results from micro level calculations like [29,39] or this paper.

\subsection{The System Boundaries of Household Consumption}

The material resource use by households includes, in principle, any natural material resources required for, first, producing and using materials, products, and services private households consume, for, second, any other activities performed by or covering the needs of households, and for, third, disposing of the related materials and products. 
When taking a life-cycle perspective, nearly any human activity can be defined as serving private households at a certain point of time. Thus, basically most of the production and consumption system of an economy can be attributed to private households. However, in this paper we attribute to households only consumption components that households are able to influence and exclude mainly public activities. For example, the resource use caused by public administration, like ministries and authorities or the defense budget, cannot be directly influenced by household consumption despite contributing in fulfilling the human needs of security and participation in society. We also exclude public services, such as health care and education, of which the resource intensity is known only to a small extent and which are also mainly part of public consumption and out of households' direct influence in Finland. In addition, water supply and waste-water treatment are excluded from the calculations because households influence the material footprint of these public services only to a limited extent. However, the energy required for heating the water is part of the calculations. On the basis of earlier results [39], the consumption components of packaging and waste management were left out because of their low relevance in comparison to the total material footprint of the households.

The household system as studied in this paper is divided into the following consumption components pragmatically defined on the basis of people's everyday life:

(1) Nutrition, including all the foodstuffs and drinks consumed;

(2) Housing, including the housing infrastructure, as well as the use of energy (electricity and heating) for household purposes;

(3) Household goods, including the 12 product groups used by Kotakorpi et al. [39]: clothes, home textiles, furniture, electric appliances, electronic appliances, paper products, jewellery, dishes, tools, toys and leisure equipment, daily consumer goods, other goods;

(4) Mobility, including the use of cars, bicycles and public transport for both everyday mobility and tourism;

(5) Leisure activities including sport and cultural activities either actively or as a spectator;

(6) Other purposes, including goods or services consumed, e.g., accommodation during holiday trips, but excluding services provided by public systems like health care and education.

\subsection{Basic Methodological Procedures and Assumptions}

The level of a sustainable material footprint for household consumption in 2050 is reasoned in Section 4.1 on the basis of the sustainable level for the total material consumption (TMC) for European countries proposed by Bringezu [3]. Macroeconomic calculations divide the TMC into private consumption, public consumption, and capital formation (e.g., [2,40]). From the micro level perspective that deals with the whole life cycle or value chain of products, capital formation is part of the life cycle of products and services because infrastructure, for instance, has to be taken into account in MIPS calculations [31]. Therefore, the TMC needs to be distributed only between public and private consumption. On the basis of their relation in present TMC results $[2,37,40,41]$, we roughly break up the sustainable level of TMC into 80 percent for household consumption and 20 percent for public consumption.

While the sustainable level of material footprint for household consumption suggested is based on existing literature, the target level for the different consumption components can differ and allow 
trade-offs according to individual needs and preferences. For example, someone who is not travelling at all could have a higher material footprint for housing and, thus, "afford" more living space. This serves the establishment of a diversity of possible development paths, as well as strategic acceptance, awareness and responsibility for the desired change with the actors involved (see [17]).

For the basic allocation of the sustainable material footprint level to the different consumption components, the four following aspects have been considered: First, basic needs (nutrition, housing, household equipment) were considered before allocating material footprints to other activities (mobility, leisure activities, other purposes). The basic needs identified are in line with the observations of Lettenmeier et al. [29] on the material footprint of households living on low social standards.

Second, we used results, experiences and conclusions from household level studies [29,39,42] to define a potential future level of material footprint in each consumption component.

Third, results from resource efficiency potential analyses (e.g., [43,44]) and other examples of promising practices were utilized for exploring future possibilities of sustainable consumption patterns. This includes examples of developments or niche solutions already accepted or promoted although still far from mainstream. This part of the research contains also websites and grey literature because only a part of the examples has been described in peer-reviewed scientific literature.

Fourth, as household consumption is an extremely broad topic, it would not have been possible to cover all research done and examples available in this paper. Therefore, the examples used are mainly based on projects, contexts and publications the authors have been involved in. Even with this relatively restrictive approach, plenty of examples became available showing the huge opportunities for developing future sustainable lifestyles and technologies.

For the consideration and calculation of the material footprints of the different consumption components in 2050, the assumption was made that future resource intensities of materials, products and activities will be lower than today. For example travelling $3000 \mathrm{~km}$ by bike, bus, tram, metro, or ferry requires approximately 1 ton of material footprint today. For the future, we assumed that improvements in materials, production processes, and capacity use of both infrastructure and vehicles should allow $5000 \mathrm{~km}$ of travelling out of 1 ton of material footprint. These material intensity assumptions are basically artificial. Their plausibility was based on a range of studies on existing material intensities and resource efficiency potentials already identified (Appendix). The assumptions used are given in a structured table for each of the consumption components (Tables 2-7).

\section{Literature Review on the Present and Sustainable Resource Use by Households}

\subsection{Present Level, Composition and Diversity of Resource Use}

The total material footprint of an average Finn is 40 tons per capita in a year $[45,46]$. This average material footprint was calculated from a micro level approach though utilizing a mixture of statistical and survey data published by different sources from 2005 to 2007 . This makes it comparable to the material footprints calculated for specific households described below. Mobility, housing, and nutrition make up $84 \%$ of the average Finn's material footprint (recalculated on the basis of $[45,46]$ ). Compared to other studies on the environmental impact of consumption [47-49], this is a similar, though even slightly bigger, share of these central consumption components. 
Kotakorpi et al. [39] calculated the material footprints of 27 Finnish households from questionnaires and diaries of the actual consumption of these households. With an average material footprint of 39 tons per person in a year, the results show a huge diversity both in level (maximum difference of factor 9, from 13 to 118 tons) and composition of the material footprints. The diversity in both terms continues when disaggregating the different consumption components into subcomponents. Nutrition shows a factor 3 difference in the material footprint levels while the differences in the other consumption components range from factor 11 for household goods to factor 85 for mobility [39] (pp. 44-60).

Lettenmeier et al. [29] report the material footprints of 18 Finnish low-income single households ranging between 7 and 35 tons per person in a year with an average of 18 tons. In general terms, both the absolute levels of and the diversity among the material footprints of the participants were lower than in [39]. With a range from 7.4 to 35.4 tons per person the maximum difference in the footprint level is slightly below factor 5 and all households are below the average Finn's level. Housing has the greatest share in the material footprints and nutrition is second with most of the households. Housing, nutrition and household goods are the only consumption components with a material footprint higher than zero for each of the 18 participants.

Lettenmeier et al. [50] calculated the material footprint for different decent minimum reference budgets developed by the Finnish National Consumer Research Centre [51]. The material footprints for these reference budgets, i.e., for the minimum living standard Finnish inhabitants should be able to achieve, ranged from 20 to 24 tons per person in a year, depending on the household type [50].

The average annual material footprint of Europeans today is estimated as being between 27 and 40 tons per capita by Groezinger et al. [52]. An average European's material footprint from 22 to 26 tons per person in a year was reported by Kuittinen et al. [16]. That study calculated the material footprint of 69 individual consumers from mostly European countries on the basis of a web questionnaire (see [16]). The material footprints of the participating individuals ranged from 8.5 to 69 tons per person in a year [16] but exclude some aspects included in the other studies described (e.g., leisure activities and water consumption). Kuittinen et al. [16] stress the importance of the diversity in the households' lifestyles and their material footprints now and in the future. They show the examples of seven participants in terms of material footprint level and diversity, explaining factors behind them (e.g., "compact home and the life nearby" or "big home and moving around"), as well as potential future development and preferences.

Finnish macroeconomic calculations give values from 14 to 31 tons per person in a year [45,53]. German macro-based values for household consumption are reported from 22 tons per person in a year [2] to 29 tons, respectively [38]. Macroeconomic data tend to show lower values for the resource use of household consumption because of differing system boundaries and allocation procedures, for instance by allocating the material input for building infrastructure in a different way (see Section 2.1).

\subsection{Sustainable Future Level of Resource Use}

The need for a general dematerialisation in order to decrease global environmental problems has been stated already for several decades [28,54-56]. However, unlike the ecological footprint the sustainable boundaries of which are set by the productive land area our planet is providing, the determination of a sustainable material footprint level is complex and not unambigous. 
By suggesting, in 1993, that global resource consumption should be halved by the middle of the 21 st century and an equal per capita use should be achieved, Schmidt-Bleek [28] claimed a factor of 10 as a necessary, but not sufficient, transformation goal for industrialized countries. Bringezu [3] applied this to the global extraction of abiotic resources, which amounted to about 100-110 billion tons in 2000 (16 to 18 tons per capita). If that amount is reduced by half and then shared equally by nine billion people in 2050, the acceptable level of abiotic resource use would be approximately 5.6-6.1 tons per capita. With the EU per capita consumption of 33.4 tons this requires a reduction by at least $80 \%$ or a factor of 5. This is in line with the suggestion of Ekins et al. [57] of six tons of abiotic resources per person in a year. It also includes the aspect of a fair share of resource use within the environmental space provided by the planet as proposed by Spangenberg [5].

For European countries, Bringezu [3] proposes a sustainable level of biotic material use and top soil erosion in agriculture and forestry of four and 0.2-0.3 tons, respectively. Including abiotic resources this means a sustainable TMC of approximately 10 tons per capita in a year.

Since 2000, global resource extraction has risen further and with a stronger growth rate than in the previous decade [1]. The used extraction increased from 2000 to 2008 by 27 percent to 68 billion tons (abiotic and biotic). Business as usual would cause a further increase globally $[58,59]$. Thus, from the perspective of recent development, a return to the global resource use in 2000 would be progress already [60]. Bringezu therefore revised his original proposal [3] and proposed a global abiotic TMC of 11-12 tons per capita per year in order to not exceed the resource use level of the year 2000 while, for the EU, with most of its housing and mobility infrastructure already built, he considers plausible a level of 10 tons, respectively [60]. However, the considerations behind this are rather related to political target-setting than to new scientific findings on the planetary boundaries. Therefore, we still use Bringezu's [3] original target of 10 tons of TMC in total as the starting point for this paper. The distribution of these 10 tons into household consumption and public consumption for this study is explained in Section 2.3.

\section{Results and Discussion}

This section first gives a suggestion on the sustainable level of material footprint for household consumption and one example on how to allocate it to the different consumption components. In Sections 4.2-4.7 the values suggested for each consumption component are explained and reasoned on the basis of already existing technologies, solutions, concepts, and other developments.

\subsection{A Sustainable Lifestyle of Eight Tons Material Footprint}

On the basis of Section 2.3, we propose a share of eight tons per person in a year for household consumption and two tons for public consumption, respectively. In order to make this amount of resource use operationable, it has to be allocated to the different consumption components. In the case of real households this aggregation depends on the specific needs, wants, lifestyles, situation, location, etc. of a household. Table 1 gives a summary on the material footprint recently reported for Finnish households (on the basis of [45] and [46] which used statistical data published from 2005 to 2007), the suggestion for a future material footprint, and the reduction required in the different consumption 
components. The order of the different consumption components proceeds from most basic needs to less basic needs, as explained in Section 2.3.

Table 1. Summary of status quo material footprints and proposal for sustainable material footprint requirements in the different consumption components.

\begin{tabular}{lcccccc}
\hline \multirow{2}{*}{$\begin{array}{l}\text { Consumption } \\
\text { component }\end{array}$} & \multicolumn{2}{c}{ Status quo material footprint } & \multicolumn{2}{c}{ Sustainable material footprint } & \multicolumn{2}{c}{ Change required } \\
\cline { 2 - 7 } & $\mathbf{k g} /($ person $\cdot \mathbf{a})$ & Share & $\mathbf{k g} /($ person $\cdot \mathbf{a})$ & Share & $\mathbf{\%}$ & Factor \\
\hline Nutrition & 5,900 & $15 \%$ & 3,000 & $38 \%$ & $-49 \%$ & 2.0 \\
Housing & 10,800 & $27 \%$ & 1,600 & $20 \%$ & $-85 \%$ & 6.8 \\
Household goods & 3,000 & $7 \%$ & 500 & $6 \%$ & $-83 \%$ & 6.0 \\
Mobility & 17,300 & $43 \%$ & 2,000 & $25 \%$ & $-88 \%$ & 8.7 \\
Leisure activities & 2,000 & $5 \%$ & 500 & $6 \%$ & $-75 \%$ & 4.0 \\
Other purposes & 1,400 & $3 \%$ & 400 & $5 \%$ & $-71 \%$ & 3.5 \\
Total & $\mathbf{4 0 , 4 0 0}$ & $\mathbf{1 0 0} \%$ & $\mathbf{8 , 0 0 0}$ & $\mathbf{1 0 0 \%}$ & $\mathbf{- 8 0 \%}$ & $\mathbf{5 . 1}$ \\
\hline
\end{tabular}

Sections 4.2-4.7 provide the central facts, assumptions and features on the material footprint level for each consumption component in a structured table and in text. Central assumptions and other relevant information are given in the text before each table. The tables contain the following issues. The resource use reduction required is given in absolute (tons) and relative (factor $\mathrm{X}$ ) terms. The amount of direct consumption, the material intensity and the share in households' total material footprint is listed for the recently reported consumption of an average Finn and the proposed future average. Multiplying the present direct consumption amount with the present or future material intensity factor results in the present or future material footprint level for each consumption component. This is followed by a core statement on ways and strategies for achieving the future material footprint.

More detailed examples, arguments and promising practices for the different consumption component is given in Tables A1-A6. These are provided from both a consumption and a production point of view as results reasoning that the material intensity and the amount of service proposed can be seen plausible.

We have to emphasize that the material footprint reduction requirements presented are suggestions on an average basis. However, different households and individuals have very diverse needs, wants, locations, and other circumstances affecting their present material footprints. Therefore, their future material footprint distribution can also vary considerably [16]. As long as the average future material footprints of households do not exceed eight tons per person in a year, the individual footprints can highly differ from each other.

\subsection{Nutrition}

The average material footprint for nutrition requires a reduction by half from present (see Table 2). The level suggested here is based on a highly but not totally vegetarian nutrition, a slightly smaller amount of foodstuffs (600 kg/(person-a)) consumed compared to today, and efficiency gains in the food chain, e.g., by reducing waste. Table A1 shows arguments for determining a sustainable material footprint for nutrition at three tons per person in a year. This value includes both food and drinks.

A reduction by a factor of 2 is a smaller reduction than with the other consumption components. Thus, the share of nutrition in the total material footprint will considerably increase in the future while 
the shares of the other consumption components either decrease or just slightly increase (see Table 1). This is because nutrition can be considered the most basic need represented in the consumption components.

Table 2. Sustainable material footprint proposal for nutrition.

\begin{tabular}{|c|c|c|c|c|c|}
\hline \multicolumn{6}{|c|}{ Nutrition-from 5.9 to 3 tons $/($ person $\cdot a)$} \\
\hline \multirow{2}{*}{ Reduction required by } & \multirow{2}{*}{\multicolumn{2}{|c|}{ Factor 2}} & \multirow{2}{*}{$\begin{array}{c}\text { Direct consumption } \\
\text { amount }\end{array}$} & Present & 840 kg (including drinks) [45] \\
\hline & & & & Future & $600 \mathrm{~kg}$ (including drinks) \\
\hline \multirow{2}{*}{$\begin{array}{l}\text { Share in household's } \\
\text { material footprint }\end{array}$} & Present & $15 \%$ & \multirow{2}{*}{ Material intensity } & Present & $7 \mathrm{~kg} / \mathbf{k g}$ (including drinks) [45] \\
\hline & Future & $38 \%$ & & Future & $5 \mathrm{~kg} / \mathrm{kg}$ (including drinks) \\
\hline Core statement & $\begin{array}{r}\text { The mater } \\
\text { - by r } \\
\text { enjo } \\
\text { - by d } \\
\text { dairy } \\
\text { - } \text { and } \\
\text { wast }\end{array}$ & $\begin{array}{l}\text { footprir } \\
\text { cing the } \\
\text { le level } \\
\text { loping a } \\
\text { oducts; } \\
\text { increasi } \\
\text { reventio }\end{array}$ & $\begin{array}{l}\text { re nutrition can be red } \\
\text { heunt of food and drin } \\
\text { he resource efficienc }\end{array}$ & $\begin{array}{l}\text { d from } 5 \\
\text { consume } \\
\text { the food }\end{array}$ & $\begin{array}{l}\text { o } 3 \text { tons/(person·a): } \\
\text { a healthy and still } \\
\text { ds notably less meat and } \\
\text { ain e.g., through }\end{array}$ \\
\hline
\end{tabular}

\subsection{Housing}

Housing is another very basic need. The suggested 85 percent reduction in the material footprint of housing is based on a decrease in living space per person by nearly half to an average of $20 \mathrm{~m}^{2}$ per person while the energy and resource efficiency of houses would increase drastically. In addition a decrease in electricity use to $1000 \mathrm{kWh}$ per person in a year and a notable increase in the resource efficiency of the electricity produced will be necessary and can be expected.

Table 3 shows the consequences of and Table A2 arguments for suggesting a sustainable material footprint for housing at 1.6 tons per person in a year. This value includes both the building and the energy used in the building.

Table 3. Sustainable material footprint proposal for housing.

\begin{tabular}{|c|c|c|c|c|}
\hline \multicolumn{5}{|c|}{ Housing - from 10.8 to 1.6 tons/(person $\cdot a)$} \\
\hline \multirow{2}{*}{ Reduction required by } & \multirow{2}{*}{ Factor 6.8} & \multirow{2}{*}{$\begin{array}{c}\text { Direct } \\
\text { consumption } \\
\text { amount }\end{array}$} & \multicolumn{2}{|c|}{ 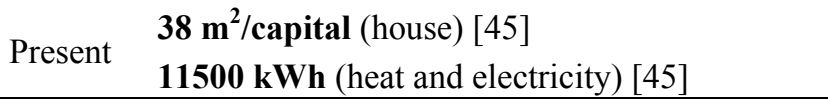 } \\
\hline & & & Future & $\begin{array}{l}\mathbf{2 0} \mathbf{~ m}^{2} / \text { capital (zero energy house) } \\
1000 \mathrm{kWh} \text { (electricity) }\end{array}$ \\
\hline \multirow{2}{*}{$\begin{array}{l}\text { Share in household's } \\
\text { material footprint }\end{array}$} & Present $\quad \mathbf{2 7} \%$ & \multirow{2}{*}{$\begin{array}{l}\text { Material } \\
\text { intensity }\end{array}$} & Present & 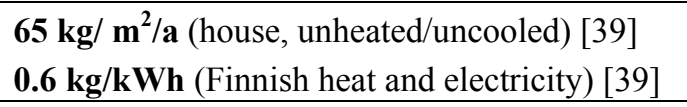 \\
\hline & Future & & \multicolumn{2}{|c|}{$\begin{array}{ll} & 65 \mathrm{~kg} / \mathrm{m}^{2} / \mathbf{a} \text { (house, heated } / \text { cooled) } \\
\text { Future } & 0.3 \mathrm{~kg} / \mathbf{k W h} \text { (European electricity) } \\
\end{array}$} \\
\hline Core statement & \multicolumn{4}{|c|}{$\begin{array}{l}\text { The material footprint for housing can be reduced from } 10.8 \text { to } 1.6 \text { tons/(person·a): } \\
\text { - by developing zero-energy houses not exceeding present houses' material intensity } \\
\text { (i.e., strongly combining energy and resource efficiency); } \\
\text { - by drastically shifting electricity production from fossils to renewables, especially wind } \\
\text { an solar energy; and } \\
\text { - } \text { by decreasing individual living space. The impacts of the latter on the individual } \\
\text { wellbeing can be reduced by increasing shared living space and improving public space } \\
\text { more liveable and attractive. }\end{array}$} \\
\hline
\end{tabular}


The material footprint proposed requires a huge change in building infrastructure as most houses are far from a zero energy standard at present. Presently existing buildings that will still be in use by 2050 cannot necessarily be assumed to be zero energy houses then. This means that the additional material inputs required for heating those houses in the future have to be compensated, e.g., by increasing the benefit provided by them or decreasing their material input in a way or another. For example, longevity and renewable energy can open additional options for reducing the material intensity of existing buildings. On the other hand, increasing urbanization is still going in Finland. This provides opportunities for establishing a much more energy and resource efficient stock than previously if resource efficiency is developed and taken into account in new buildings and quarters. In addition, increasing urbanization can help to achieve the mobility proposals given in Section 4.5.

\subsection{Household Goods}

A part of the household goods we are using can be considered as basic need. However, as the amount of household goods used on average today certainly exceeds the most basic needs, a reduction of 83 percent is suggested for the material footprint of producing the goods households use (Table 4). This should be achieved by a decrease in ownership as well as an increase in longevity, reuse, second-hand use, sharing, and other options. Table A3 shows arguments for this proposal.

Table 4. Sustainable material footprint proposal for household goods production.

\begin{tabular}{|c|c|c|c|c|}
\hline \multicolumn{5}{|c|}{ Household goods production (cradle to retail) — from 3 to 0.5 tons/(person $\cdot a)$} \\
\hline \multirow[t]{2}{*}{ Reduction required by } & \multirow[t]{2}{*}{ Factor 6} & \multirow{2}{*}{$\begin{array}{l}\text { Direct consumption } \\
\text { amount }\end{array}$} & Present & $\begin{array}{l}1943 \text { items/household (avg), out of which } \\
568 \text { second hand or similar [39] }\end{array}$ \\
\hline & & & Future & less own items \\
\hline \multirow[t]{2}{*}{$\begin{array}{l}\text { Share in household's } \\
\text { material footprint }\end{array}$} & Present $\mathbf{7 \%}$ & \multirow[t]{2}{*}{ Material intensity } & Present & $\begin{array}{l}200 \mathrm{~kg} /(\text { person } \cdot \mathbf{a}) \text { as an average for the } \\
12 \text { product groups, with a range from } 15 \text { to } \\
420 \mathrm{~kg} /(\text { person } \cdot a) \text { per one product group } \\
\text { and with only } 3 \text { product groups below } \\
170 \mathrm{~kg} /(\text { person } \cdot a)[39]\end{array}$ \\
\hline & Future $\quad 6 \%$ & & Future & $\begin{array}{l}42 \mathbf{k g} /(\text { person } \cdot \mathbf{a}) \text { on average for each of } \\
\text { the } 12 \text { product groups }\end{array}$ \\
\hline Core statement & $\begin{array}{l}\text { The material fo } \\
\text { increasing long } \\
\text { improving reus }\end{array}$ & $\begin{array}{l}\text { tprint for household } \\
\text { andy, decreasing own } \\
\text { and second hand sch }\end{array}$ & $\begin{array}{l}\text { ods can t } \\
\text { mes, etc. }\end{array}$ & $\begin{array}{l}\text { reduced from } 3 \text { to } 0.5 \text { tons/(person } \cdot a) \text { by } \\
\text { lipment, increasing sharing options, }\end{array}$ \\
\hline
\end{tabular}

Recycling and reuse (e.g., second hand products or reuse of components in appliances) usually cause particularily low material footprints because in the MIPS concept the material input is allocated to the original material or product produced. For additional using times afterwards only the material input for reintegrating the material or product into the market (e.g., sorting plants, washing, transportation) is calculated [31].

This section covers the material footprint for the production of the 12 product groups used by Kotakorpi et al. [39] with a life cycle "from cradle to retail". The resource use during the use phase of the products is covered by Section 4.3. Because all electricity and energy used at homes is allocated to the consumption component of housing, and households usually receive only one electricity bill for all 
the power consumed at home (see also [59]). Furthermore, the transportation of goods from retail to home is included in the mobility figures.

\subsection{Mobility}

Mobility has a strong influence on the present average material footprint (Table 1). The diversity of different activity profiles concerning mobility is huge [16] (pp. 24-41), [29] (pp. 1436-1438) and [39] (pp. 48-49).

The greatest average reduction ( $88 \%$, i.e., close to a factor of 9$)$ we suggest is for this consumption component. It can be achieved by reducing private car traffic to a fraction of present levels. In addition a reduction of overall mobility performance to $10,000 \mathrm{~km}$ per person in a year is required while simultaneously increasing the resource efficiency of public transport from present.

Table 5 shows the central consequences and Table A4 the arguments for determining a sustainable material footprint for mobility at 2 tons per person in a year. This value includes both everyday mobility (e.g., trips to work, shopping and leisure activities) and tourism-related transportation (but excludes trips that are done on behalf of the employer). This means that also the composition of a sustainable material footprint for mobility can differ according to a person's individual needs and interests. Table 5 shows a range of values for present mobility in the case of aeroplanes, trains, and other transport subsystems because the huge differences in both material intensity and function between, for instance, local and long-distance trains or domestic and intercontinental flights are too big to be covered by one single average value.

Table 5. Sustainable material footprint proposal for mobility.

\begin{tabular}{|c|c|c|c|c|c|}
\hline \multicolumn{6}{|c|}{ Mobility — from 17.3 to 2 tons/(person $\cdot a)$} \\
\hline \multirow{2}{*}{ Reduction required by } & \multirow{2}{*}{\multicolumn{2}{|c|}{ Factor 8.7}} & \multirow{2}{*}{$\begin{array}{c}\text { Direct consumption } \\
\text { amount }\end{array}$} & Present & $17,500 \mathrm{~km}$ \\
\hline & & & & Future & $10,000 \mathrm{~km}$ \\
\hline \multirow[t]{2}{*}{$\begin{array}{l}\text { Share in household's } \\
\text { material footprint }\end{array}$} & Present & $43 \%$ & \multirow[t]{2}{*}{ Material intensity } & $\begin{array}{c}\text { Present } \\
\text { [61] }\end{array}$ & $\begin{array}{l}1.44 \mathrm{~kg} / \text { person-km* (private car) } \\
0.53-1.2 \mathrm{~kg} / \text { person-km (train) } \\
0.06-0.56 \mathrm{~kg} / \text { person-km (plane) } \\
0.26-0.38 \mathrm{~kg} / \text { person-km (bus, coach, } \\
\text { tram, metro, ferry, bike) }\end{array}$ \\
\hline & Future & $25 \%$ & & Future & $0.2 \mathrm{~kg} /$ person-km \\
\hline Core statement & $\begin{array}{l}\text { The mate } \\
\text { - by } 1 \\
\text { - by } 1 \\
\text { - by } 1 \\
\text { - by } \\
\text { livi } \\
\text { allo } \\
\text { - by }\end{array}$ & $\begin{array}{l}\text { l footp } \\
\text { king pu } \\
\text { ucing } t \\
\text { iting th } \\
\text { inging } \\
\text { enviror } \\
\text { a reduc } \\
\text { integra }\end{array}$ & $\begin{array}{l}\text { t for mobility can be } \\
\text { ic transport and bikin } \\
\text { role of private cars d } \\
\text { amount of kilometres } \\
\text { vel requirements for } \\
\text { ent as well as the cha } \\
\text { in mobility and trar } \\
\text { e management of mo }\end{array}$ & $\begin{array}{l}\text { duced fro } \\
\text { still mor } \\
\text { matically } \\
\text { avelled t } \\
\text { ork and le } \\
\text { ge of pro } \\
\text { ports; } \\
\text { ility and }\end{array}$ & $\begin{array}{l}\text { m } 17.3 \text { to } 2 \text { tons/(person·a): } \\
\text { resource-efficient; } \\
10,000 \mathrm{~km} /(\text { person·a); } \\
\text { sure, e.g., by a higher attractiveness of the } \\
\text { uction and communication structures that } \\
\text { CT options. }\end{array}$ \\
\hline
\end{tabular}




\subsection{Leisure Activities}

Leisure activities are important because they provide recreation and health to people who are often doing one-sided work. The material footprint for leisure activities is suggested to be reduced from present by 75 percent. This should be possible by reducing especially resource-intensive activities and products, by keeping the amount of activities and products on a sufficient level and by increasing the resource efficiency of the activities or products.

Table 6 shows the central consequences and Table A5 the arguments for determining a sustainable material footprint for leisure activities at 0.5 tons per person in a year. This value focuses basically on activities out of the home because activities within homes are covered by the consumption components of household goods and housing. The material footprints reported for basic leisure activities at home have been relatively low, for example $1 \mathrm{~kg} / \mathrm{h}$ for watching TV or $2 \mathrm{~kg}$ per shelf centimeter of books [39]. However, if leisure activities at home could also be allocated to this consumption component if they require a huge amount of additional resources, e.g., for equipment.

Table 6 shows a range of values for common leisure activities. They appear to follow a rough pattern according to which they can be divided into

(1) low-infrastructure activities with low material footprints, such as jogging;

(2) group or mass activities with an apparent need for infrastructure, such as using a swimming hall or fitness club, thus requiring a higher amount of resources; and

(3) highly individual and/or infrastructure-intensive activities showing also the highest material footprints, such as golf or sailing.

Table 6. Sustainable material footprint proposal for leisure activities.

\begin{tabular}{|c|c|c|c|c|}
\hline \multicolumn{5}{|c|}{ Leisure Activities-from 2 to 0.5 tons/(person $\cdot a)$} \\
\hline \multirow{2}{*}{$\begin{array}{l}\text { Reduction } \\
\text { required by }\end{array}$} & \multirow{2}{*}{ Factor 4} & \multirow{2}{*}{$\begin{array}{l}\text { Direct consumption } \\
\text { amount }\end{array}$} & Present & $\begin{array}{l}\mathbf{3 . 5} \mathbf{h} \text { of physical exercise or other leisure } \\
\text { activities outside the home [45] }\end{array}$ \\
\hline & & & Future & $\begin{array}{l}\mathbf{3} \mathbf{h} \text { but strongly dependent on the material } \\
\text { intensity of the activity }\end{array}$ \\
\hline \multirow[t]{2}{*}{$\begin{array}{c}\text { Share in } \\
\text { household's } \\
\text { material footprint }\end{array}$} & Present $\quad \mathbf{5 \%}$ & \multirow[t]{2}{*}{ Material intensity } & $\begin{array}{c}\text { Present } \\
\text { [39] }\end{array}$ & $\begin{array}{l}\mathbf{1 ~ k g / h} \text { for low-infrastructure outdoor activities; } \\
\mathbf{5}-\mathbf{1 5} \mathbf{~ k g} / \mathbf{h} \text { for activities requiring infra-structure } \\
\text { like buildings, harbours, slopes; } \\
\geq \mathbf{3 0} \mathbf{~ k g / h} \text { for resource-intensive individu-al } \\
\text { activities like sailing, golf, motor sport }\end{array}$ \\
\hline & Future $\quad 6 \%$ & & Future & $\begin{array}{l}\text { 1-6 kg/h (e.g., } 2 \times 50 \mathrm{~h} / \mathrm{a} \times 1 \mathrm{~kg} / \mathrm{h}+1 \times 50 \mathrm{~h} / \mathrm{a} \\
\times 6 \mathrm{~kg} / \mathrm{h})\end{array}$ \\
\hline Core statement & \multicolumn{4}{|c|}{$\begin{array}{l}\text { The material footprint for leisure can be reduced from } 2 \text { to } 0.5 \text { tons/(person·a): } \\
\text { - by rather decreasing than increasing leisure activities that are highly material intensive and/or } \\
\text { require built and heated infrastructure; } \\
\text { - by utilizing outdoor options requiring few resources (walking, jogging, canoeing, gardening, ...); } \\
\text { - } \text { by using infrastructure more efficiently (e.g., schools in the evening); and } \\
\text { - by making leisure activities more resource efficient (e.g., longevity of venues, resource } \\
\text { efficient use of energy). }\end{array}$} \\
\hline
\end{tabular}


The latter of these will have the greatest needs for decreases in material intensity, improved resource management, and/or trade-offs with other consumption components in the future, depending on the needs and interests of individuals and households.

\subsection{Resource Use for Other Purposes}

As this concumption component, in principle, covers anything not covered by the previous ones no direct consumption amount nor material intensity has been specified in Table 7. In addition the reduction required in reality is probably higher than proposed because, for example, the consumption of many services is not yet included in the calculations so far (see Section 2.1 for details). Other purposes could include, e.g., services or accommodation during holiday trips (see also Table A6).

Table 7. Sustainable material footprint proposal for other purposes.

\begin{tabular}{|c|c|c|c|c|}
\hline \multicolumn{5}{|c|}{ Other purposes-from 1.4 to 0.4 tons/(person $\cdot a)$} \\
\hline Reduction required by & \multicolumn{2}{|c|}{ Factor 3.5} & Direct consumption amount & not specified \\
\hline \multirow{2}{*}{$\begin{array}{l}\text { Share in household's } \\
\text { material footprint }\end{array}$} & Present & $3 \%$ & \multirow{2}{*}{ Material intensity } & \multirow{2}{*}{ not specified } \\
\hline & Future & $5 \%$ & & \\
\hline Core statement & \multicolumn{4}{|c|}{$\begin{array}{l}\text { The material footprint for other purposes should be reduced from } 1.4 \text { to } 0.4 \\
\text { tons/(person·a) in order to keep the material footprint of household } \\
\text { consumption within the limits of } 8 \text { tons/(person } \cdot \text { a). }\end{array}$} \\
\hline
\end{tabular}

\section{Conclusions}

This paper provides a basic reference framework for achieving sustainable household consumption by 2050. In general, a sustainable household consumption in 2050 seems achievable on the basis of the mostly Finland-related proposals of the paper (Section 4). However, the targets proposed (see Table 1-7) show that there is a long way to go and a lot of efforts required (see also Appendix, Tables A1-A6). The findings of this study can help to show the way towards sustainable household consumption and are intended to contribute to a positive vision for the enormous transformation task we are facing.

For the suggested average factor 5 of reduction in material footprint (see Table 1), a factor 2 to 3 improvement appears necessary in terms of both production-based and consumption-based solutions (see Appendix, Tables A1-A6 for examples). By developing four different scenarios for achieving sustainable lifestyles by 2050, Leppänen et al. [62] have shown that the transition to sustainable lifestyles can have very different faces. They defined some common features of the different scenarios that can be confirmed by the results in Section 4 . These aspects are:

- A reduced consumption of meat and other animal-based foodstuffs;

- A radical reduction of the heating and cooling energy demand of houses;

- A strongly dematerialized, fossile-free electricity production, and a lower level of mobility including a drastically decreased use of private cars.

The more technology and infrastructure can be integrated into this change, the more space will be left for individual diversity in achieving sustainable household consumption. However, even with advanced developments in technology and infrastructure the role of basic needs, especially nutrition, and their satisfaction is likely to increase strongly in the future (see Table 1). 
Households have space for even immediate decisions decreasing the material footprint. In the fields of nutrition, electricity procurement and tourism, for instance, sustainable decisions can be made any time so that even fast changes could be envisaged in these areas. Although households are, in principle, free to make decisions on their consumption, some decisions are highly complex and can be locked into existing infrastructures (see $[16,39,63,64]$ ). For instance, housing-related decisions are done rarely compared to e.g., nutrition choices and the location of housing affects many further decisions, e.g., the mobility options available. Therefore, incentives should be set to facilitate change in public planning and decisions, for example on infrastructure.

Infrastructure affects resource use in the long run and determines lifestyles in many respects. Therefore, including the aspect of facilitating sustainable, low-resource lifestyles in public decision-making provides an opportunity for avoiding misinvestments and creating synergies from options simultaneously decreasing the resource use of several consumption components. For example, promoting car-free lifestyles in city planning can reduce car use and the need for public and private infrastructure like streets and parking space. Thus, it can decrease the material intensity of both mobility and housing. Attractive car-free quarters can reduce the highly relevant (see $[65,66])$ need for leisure time trips and could possibly also reduce the need for private living space. Without a car, closely situated shops and other facilities are more attractive than distant ones [67]. In addition, the health effects of decreasing car use are evident [68]. Increasing walking and cycling could, thus, also decrease the resource use required for leisure activities and for health care.

The framework given by this paper could also help preventing rebound effects of changing consumption patterns. For example, information and communication technology (ICT) has a considerable potential for decreasing mobility needs. Therefore, trade-offs between mobility, household goods and housing (electric power) should be considered. ICT can, for instance, facilitate car-sharing and public transport and monitor, control and reduce the need for lighting and heating at home. However, a challenge of ICT use is the increased need for copper and other resource-intensive materials and equipment (e.g., [69]). The material footprint of digital banking, for instance, has been reported to be still $40 \%$ in comparison to traditional banking (approximately 1.1 and $2.8 \mathrm{~kg} /$ happening, repsectively) because also digital banking requires bank infrastructure, electric power, computers, etc. [70]. In addition, Rohn et al. [71] have pointed out the need for a careful resource management in the ICT sector in order to avoid rebound effects.

Another example that can either increase or decrease resource use is collaborative consumption. Collaborative consumption is a rising trend with dematerialisation potentials in different consumption components [72]. However, if sharing consumer goods largely increases, rebound effects should actively be avoided in terms of both the overall amount of different products in use and their potential overall energy consumption and especially the potentially increasing car use for providing and acquiring products and services. This is one area further research should focus on.

Additionally, the following suggestions for further research could help to facilitate the transition challenge we are facing.

Investments in production and infrastructures highly influence what and how people consume. Therefore, it would be highly relevant to study how to use both public and private financial resources in the best way for decreasing material footprints while maintaining a high quality of life. To which extent affluent households could facilitate dematerialisation by using or allocating their financial 
resources in an optimal way and how can public earning (e.g., taxes) and spending (e.g., research and development funding) best facilitate dematerialisation instead of increasing resource use? For example, investments in energy and resource efficient buildings are urgent in order to achieve the targets proposed in Section 4.3.

There is a high demand for further research in order to make concrete and to mainstream the dematerialisation options sketched in Section 4 and Appendix. For example, resource-efficient zero-energy construction and low-energy retrofitting still require lots of questions to be solved. Both urban structures and mobility systems that reduce car dependency have been developed only to a small extent, so far.

An enlargement of the database to other countries than Finland and to other continents would help to address and compare household consumption on a broader basis. We also excluded public services the resource intensity of which is known only to a small extent although their contribution to resource use is highly relevant. Examples for this kind of services are health care and education.

This paper provides a first framework for developing household consumption towards a sustainable material footprint. Hopefully it can inspire also other researchers and practitioners to make sustainable lifestyles more attractive and concrete and to develop political and business solutions facilitating sustainable lifestyles.

\section{Acknowledgments}

The authors would like to thank Jana Meier, Lena Brüch, Sini Veuro and Satu Lähteenoja for their valuable assistance during the preparation and editing of the paper. We thank Tuuli Hirvilammi, Senja Laakso, Satu Lähteenoja, Aleksi Neuvonen, Michael Ritthoff, Fritz Hinterberger, Christine Ax and Stefan Giljum for the fruitful discussions during the development of the idea of this "8 tonnes framework". Special thanks also to the SPREAD team of Politecnico di Milano for organizing a workshop inspring to develop the " 8 tonnes concept" for sustainable lifestyles.

This paper was prepared with financial support of the project "Socio-economic practices of sustainable development in the new industrialization". The project is founded by the Government of the Russian Federation, Grant 074-U01 and conducted within the ITMO University. 


\section{Appendix}

Table A1. Promising examples and practices supporting the sustainable material footprint proposal for nutrition in detail.

\begin{tabular}{|c|c|}
\hline \multicolumn{2}{|r|}{ Nutrition-from 5.9 to 3 tons/(person $\cdot a)$} \\
\hline $\begin{array}{l}\text { Central consumption- } \\
\text { related arguments, } \\
\text { examples, promising } \\
\text { practices }\end{array}$ & $\begin{array}{l}\text { - } 6 \text { out of } 27 \text { Finnish households studied already achieve } 3200 \mathrm{~kg} \text { or less [39]; } \\
\text { - } 4 \text { out of } 18 \text { low-income single households already achieve } 3200 \mathrm{~kg} \text { or less, with one vegan } \\
\text { participant at } 2200 \mathrm{~kg} \text { [29]; } \\
\text { - } \text { Indian average diet (2007) at } 2500 \mathrm{~kg} \text {, "Livewell UK } 2020 \text { " at } 3700 \mathrm{~kg} \text { [73]; } \\
\text { - } \quad \text { Present differences in the direct consumption of selected foodstuffs (including most relevant } \\
\text { foodstuffs, excluding drinks) in European countries [42]: amount from below } 500 \text { and over } \\
700 \mathrm{~kg} / \text { (person·a), For Finland the present amount consumed according is } 540 \mathrm{~kg} /(\text { person·a) } \\
\text { and the present material intensity } 8.2 \mathrm{~kg} / \mathrm{kg} \text { (both excluding drinks) [42]; } \\
\text { - Vegan and vegetarian lifestyles presently becoming trendy in Western countries, which } \\
\text { opens people options for less resource-intensive diets; } \\
\text { Catering establisments have huge opportunities for developing and spreading low resource } \\
\text { diets, and thus for initiating behavioral change. So far, these opportunities are used rarely. } \\
\text { Their potentials have not been sufficiently analyzed so far but single examples show that } \\
\text { relevant new practices can be developed on the basis of user- and actor-integrated } \\
\text { experiments (e.g., [74] (pp. 6-9)). }\end{array}$ \\
\hline $\begin{array}{l}\text { Central production- } \\
\text { related arguments, } \\
\text { examples, promising } \\
\text { practices }\end{array}$ & $\begin{array}{l}\text { - Huge differences presently in the material intensity of selected (most relevant ones included, } \\
\text { drinks excluded) foodstuffs in selected European countries: from } 8.4 \text { to } 11.4 \mathrm{~kg} / \mathrm{kg} \text {, several } \\
\text { European countries already below } 9 \mathrm{~kg} / \mathrm{kg} \text { [42]; } \\
\text { - Cereals and bread, milk, eggs, domestic fruits, outdoor vegetables, soya, wild fish can } \\
\text { already today be below } 6 \mathrm{~kg} / \mathrm{kg}[27,39,42] \text {; } \\
\text { - Material footprints of typical lunch meals, for instance, vary between } 1.7 \text { and } 6.8 \mathrm{~kg} / \mathrm{meal}[75] \\
\text { and material intensities by factors of } 5 \text { and more [39]; } \\
\text { - The reduction of the high amount of food waste in Western countries at present offers } \\
\text { opportunities for decreasing food consumption and material intensities. German food waste } \\
\text { amount (value chain, incl. production, distribution and consumption) estimated at } \\
\text { 146 kg/(person·a) and its material footprint at } 1185 \mathrm{~kg} /(\text { person-a) [76]; } \\
\text { Also food production technologies can still be developed less resource-intensive } \\
\text { (e.g., [44] (pp.52-53)). } \\
\text { Agricultural production and practices can be developed more resource efficient } \\
\text { (e.g., [44] (pp. } 30-31,109-111) \text { ). So far, factors like animal welfare, erosion, soil quality, } \\
\text { irrigation, soil movement, etc. have usually rather been optimized in terms of cost efficiency } \\
\text { than resource efficiency. Niche solutions and concepts like permaculture show that huge } \\
\text { potential from different production practices exists (e.g., [77,78]). } \\
\text { Legal requirements and industrial standards concerning the appearance and shape of the } \\
\text { products cause unnecessary resource use in the production chain of food [79]. }\end{array}$ \\
\hline
\end{tabular}


Table A2. Promising examples and practices supporting the sustainable material footprint proposal for housing in detail.

\begin{tabular}{|c|c|}
\hline \multicolumn{2}{|r|}{ Housing-from 10.8 to 1.6 tons/(person $\cdot a)$} \\
\hline $\begin{array}{l}\text { Central consumption- } \\
\text { related arguments, } \\
\text { examples, promising } \\
\text { practices }\end{array}$ & $\begin{array}{l}\text { - } 8 \text { of } 27 \text { households already achieve } 1500 \mathrm{~kg} \text { or less for the building (excluding heating). } \\
14 \text { of } 27 \text { households already achieve } 300 \mathrm{~kg} \text { or less for electricity consumption [39]; } \\
\text { - } 20 \mathrm{~m}^{2} \text { of living space is } 55 \% \text { of present European average but also today reality for students } \\
\text { and other groups; } \\
\text { - Shared space use is an option for increasing individual living space. Co-housing is seen as a } \\
\text { promosing practice emerging in the context of sustainable living [80]; } \\
\text { - A study on residents' heating behavior using data loggers in different apartments of } \\
\text { multifamily residences found out that the heating energy consumption of flats with the same } \\
\text { floor plan differed by } 110 \% \text { [81]. Thus, the user behavior has a notable effect on heating } \\
\text { energy consumption. }\end{array}$ \\
\hline $\begin{array}{l}\text { Central production- } \\
\text { related arguments, } \\
\text { examples, promising } \\
\text { practices }\end{array}$ & 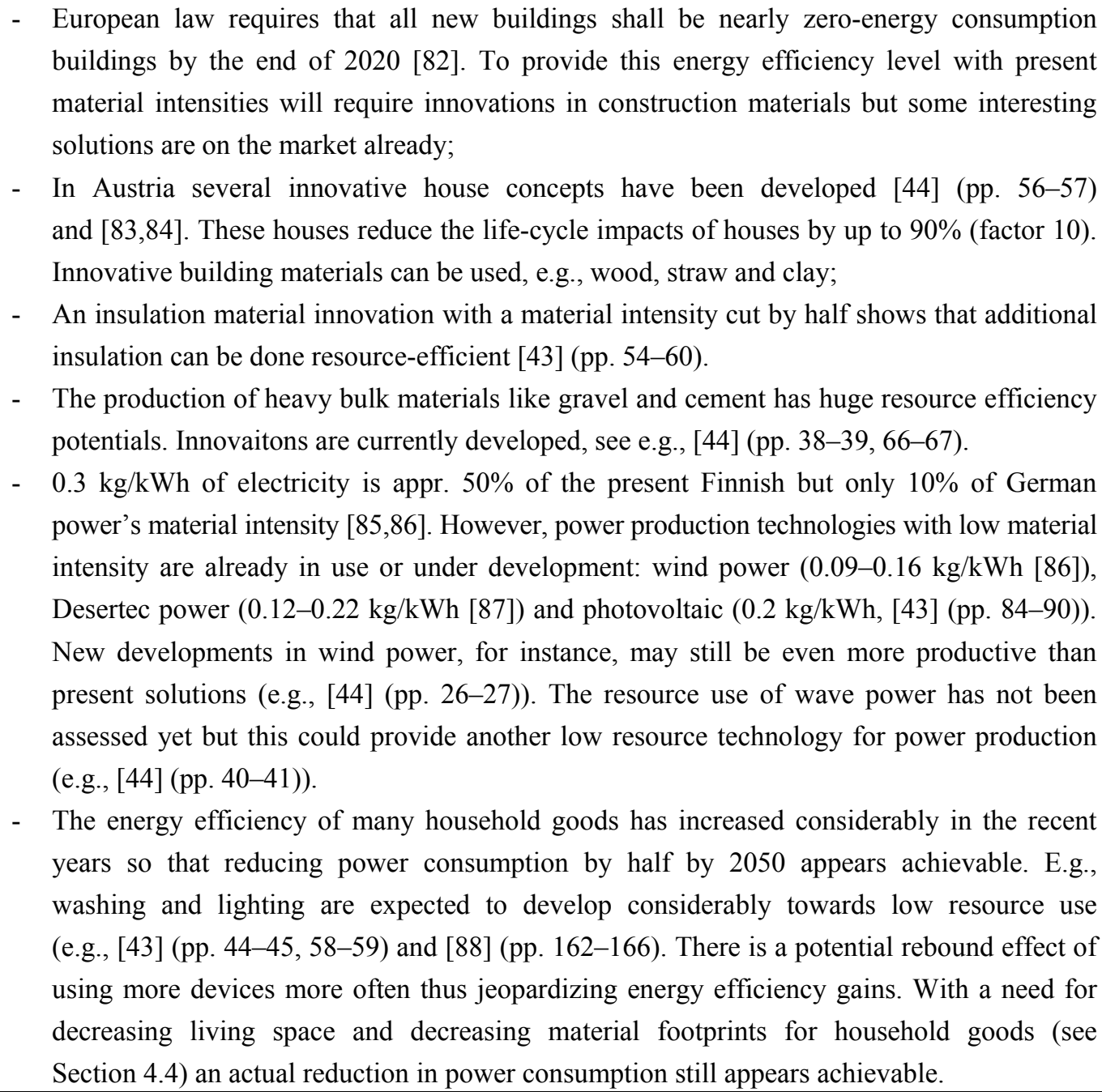 \\
\hline
\end{tabular}


Table A3. Promising examples and practices supporting sustainable material footprint proposal for household goods production.

\begin{tabular}{|c|c|}
\hline \multicolumn{2}{|r|}{ Household goods production (cradle to retail) 一 from 3 to 0.5 tons/(person $\cdot a)$} \\
\hline $\begin{array}{l}\text { Central consumption- } \\
\text { related arguments, } \\
\text { examples, promising } \\
\text { practices }\end{array}$ & $\begin{array}{l}500 \mathrm{~kg} /(\text { person } \cdot \mathrm{a}) \text { of material footprint is close to the very lowest end of the } 27 \text { Finnish } \\
\text { households ranging between } 560 \text { and } 5.900 \mathrm{~kg} /(\text { person·a) [39]. Thus, } 500 \mathrm{~kg} \text { means a } \\
\text { considerable decrease compared to today; } \\
\text { - } 3 \text { out of } 18 \text { Finnish low-income single households already achieve below } 750 \mathrm{~kg} \text { [29]. } \\
\text { Generally, the low-income households in this study tend to have smaller material footprints } \\
\text { than the households studied by [39]. This is at least partly due to second hand purchases and } \\
\text { an intensive use of public sharing services like libraries; } \\
\text { - A reduced living space per person (see Section 4.3) decreases the space and the need for } \\
\text { household goods to a certain extent (e.g., [39] (p. 68)); } \\
\text { - Among consumers swapping and sharing schemes as well as collaborative co nsumption are } \\
\text { rising trends (e.g., [80]) with clear advantages in terms of resource use (e.g., [89]). They thus } \\
\text { can decrease the need for the production of new goods notably if rebound effects are avoided. }\end{array}$ \\
\hline $\begin{array}{l}\text { Central production- } \\
\text { related arguments, } \\
\text { examples, promising } \\
\text { practices }\end{array}$ & $\begin{array}{l}\text { - Longevity and modularity for repair/reuse of products can decrease the material input per } \\
\text { year of product use notably (e.g., [88,90] for furniture, shoes and jewelry). The availablility } \\
\text { of repair and reuse services is a central factor in order to facilitate a long life of products. } \\
\text { Mobile repair services can help to make repair services accessible while preventing } \\
\text { consumers from having to drive long distances (e.g., [44] (pp. 60-61)). } \\
\text { - } \text { If a product requires energy during its use face, a long lifetime might increase total resource } \\
\text { use. However, with low material footprints for energy (as proposed in Section 4.3), } \\
\text { longevity remains a resource-efficient option (e.g., [88,91]). } \\
\text { - Increasing the share of recycled materials and/or reused components in products is another } \\
\text { option decreasing the material footprint. Especially recycled metals have considerably lower } \\
\text { material intensities (see [88] (pp. 58-61) and [92]). This can be an increasingly important } \\
\text { option for electronic products as the availability of several raw-materials of theses products } \\
\text { is predicted to decrease during the coming decades (e.g., [93,94]). Also durable jewelry has } \\
\text { a huge reuse and recycling potential [88] (pp. 58-91). } \\
\text { Numerous examples show that product design, standardization and other measures can decrease } \\
\text { both the amount of products in use and their material intensity (e.g., [44] (pp. 44-45, 50-51)). }\end{array}$ \\
\hline
\end{tabular}

Table A4. Promising examples and practices supporting sustainable material footprint proposal for mobility.

\section{Mobility-from 17.3 to 2 tons/(person $\cdot a)$}

\begin{tabular}{|c|c|}
\hline \multicolumn{2}{|r|}{ Mobility-from 17.3 to 2 tons/(person·a) } \\
\hline $\begin{array}{l}\text { Central consumption- } \\
\text { related arguments, } \\
\text { examples, promising } \\
\text { practices }\end{array}$ & $\begin{array}{l}\text { - } 2 \text { out of } 27 \text { Finnish households achieve } 2500 \mathrm{~kg} \text { or less [39]; } \\
13 \text { of } 18 \text { participants already achieve } 2000 \mathrm{~kg} \text { or less for daily mobility and } 14 \text { participants } \\
1500 \mathrm{~kg} \text { or less for tourism (most of which relates to mobility) [29]; } \\
\text { - } \quad \text { The distance of } 10,000 \mathrm{~km} \text { can mean } 40 \mathrm{~km} \text { on } 250 \text { days of the year, for instance. However, } \\
\text { with lower daily mobility also longer trips are still possible. A holiday trip of } 10,000 \mathrm{~km} \\
\text { one-way for example would be possible if daily mobility didn't exceed 10,000 km in } 3 \text { years. } \\
\text { - Car-free households studied in Vienna use public transport while reference households use a } \\
\text { car as basic means of transport. Yet, the total distances travelled and the flights made by car- } \\
\text { free households are only slightly higher than in the reference group [95]; } \\
\text { - Car-sharing can reduce the need of owning and using private cars by providing a possibility } \\
\text { of car use when it's especially necessary. }\end{array}$ \\
\hline
\end{tabular}


Table A4. Cont.

\begin{tabular}{|c|c|}
\hline & Mobility-from 17.3 to 2 tons/(person $\cdot a)$ \\
\hline $\begin{array}{l}\text { Central production- } \\
\text { related arguments, } \\
\text { examples, promising } \\
\text { practices }\end{array}$ & $\begin{array}{l}\text { - Bus transport in finnish cities already achieves an average material intensity of only } \\
0.1 \mathrm{~kg} / \text { person-km *, bike traffic in Helsinki } 0.2 \mathrm{~kg} \text {, respectively [96]; } \\
\text { - Private cars in their present use and amount can hardly be seen as a broad solution to achieve a } \\
\text { sustainable material footprint for mobility. Even wind-power-based electric drive decreases } \\
\text { the material footprint only slightly when infrastructure is not even considered [43]. } \\
\text { - } \text { Longhaul flights are presently well below, long European flights and ferry trips close to } \\
0.2 \mathrm{~kg} / \text { person-km in material intensity ( } 0.06,0.11 \text { and } 0.26 \mathrm{~kg} / \text { person-km, respectively [61]). } \\
\text { Thus, this kind of travelling would basically be possible in the future also but probably to a } \\
\text { much smaller extent than flight-intensive lifestyles are presently consuming. Compared to } \\
\text { the material footprint and other means of transport, the air consumption and carbon } \\
\text { footprints of flights are relatively high. Thus, there may occur further future needs to restrict } \\
\text { flights because of their climate impacts although peak oil is expected to reduce flying } \\
\text { dramatically long before } 2050 \text { [97]; } \\
\text { Development of low resource services concerning the social interaction needs of individuals } \\
\text { and social groups as well as basic procurement like shopping. These services should be } \\
\text { developed on the basis of low resource infrastructure because presently infrastructure } \\
\text { requires a huge share of mobility material footprints [61]. }\end{array}$ \\
\hline
\end{tabular}

Note: * kg/person-km: material input in $\mathrm{kg}$ per person transported one kilometre.

Table A5. Promising examples and practices supporting sustainable material footprint proposal for leisure activities.

\section{Leisure activities-from 2 to 0.5 tons/(person $\cdot a)$}

\begin{tabular}{|c|c|}
\hline \multicolumn{2}{|r|}{ Leisure activities-from 2 to 0.5 tons/(person $\cdot a)$} \\
\hline $\begin{array}{l}\text { Central consumption- } \\
\text { related arguments, } \\
\text { examples, promising } \\
\text { practices }\end{array}$ & $\begin{array}{l}\text { - } 2 \text { out of } 27 \text { Finnish households achieve less than } 800 \mathrm{~kg}[39] ; \\
\text { - } 13 \text { out of } 18 \text { low-income single households already achieve } 500 \mathrm{~kg} \text { or less but this is often } \\
\text { due to financial constraints [29]; } \\
\text { - } 6 \mathrm{~kg} / \mathrm{h} \text { is already achieved by activites in e.g., music schools, fitness centres or sports halls, } \\
1 \mathrm{~kg} / \mathrm{kg} \text { with e.g., jogging or rowing [39]; } \\
\text { - } \quad \text { Presently resource-intensive activities like golf or going to a theatre (see [39]) could be } \\
\text { done only sometimes per year; } \\
\text { - Activities at home can be excluded from here if they fit into the consumption components } \\
\text { of housing (e.g., electricity use, see Section 4.3) and household goods (see Section 4.4). }\end{array}$ \\
\hline $\begin{array}{l}\text { Central production- } \\
\text { related arguments, } \\
\text { examples, promising } \\
\text { practices }\end{array}$ & $\begin{array}{l}\text { - Increase in resource efficiency of activities expectable by } 2050 \text { e.g., by more efficient use } \\
\text { of infrastructure and by more resource-efficient energy use (electricity and heat, similar to } \\
\text { the requirements and achievements in housing, see Section } 4.3 \text { ). Sensitivity analyses of } \\
\text { leisure-related MIPS studies show that the longevity, the energy use and the capacity use of } \\
\text { leisure infrastructure are important factors affecting and being able to decrease material } \\
\text { footprints [65,66]. } \\
\text { - The location and accessibility of venues greatly affects mobility needs. Presently often half } \\
\text { or more of the material footprint of events or training sessions is affected by transporting } \\
\text { participants and/or spectators to the venue [39] (pp. 65-66, 69); [88] (pp. 99-107) and [90]. } \\
\text { Although mobility is covered by Section } 4.5 \text {, this is an important aspect when planning } \\
\text { leisure facilities. } \\
\text { The other parameter greatly influencing the material footprint of leasure activities is the } \\
\text { venue [65,66] and [88] (pp. 99-107). Therefore, in order to achieve lower material } \\
\text { footprints, the capacity of venues should be used as efficiently as possible, also for other } \\
\text { purposes than the original one (see e.g., [66] for additional events in theatres). Also the use } \\
\text { of schools etc. for evening or weekend events can decrease material footprints especially } \\
\text { when it decreases the need for building additional facilities. }\end{array}$ \\
\hline
\end{tabular}


Table A6. Promising examples and practices supporting sustainable material footprint proposal for other purposes.

\begin{tabular}{|c|c|}
\hline \multicolumn{2}{|r|}{ Other purposes-from 1.4 to 0.4 tons/(person $\cdot a)$} \\
\hline $\begin{array}{l}\text { Central } \\
\text { consumption-related } \\
\text { arguments, } \\
\text { examples, promising } \\
\text { practices }\end{array}$ & $\begin{array}{l}\text { - The content of this consumption component can be highly different depending on the } \\
\text { specific household. In the calculations for the average Finn the } 1400 \mathrm{~kg} \text { used here is related } \\
\text { to accommodation on holiday trips, e.g., in hotels or cottages. However, it could contain } \\
\text { something totally different, like going to events, purchasing medicine, having pets, or just } \\
\text { consuming more in other consumption components (Sections 4.2-4.6). Therefore, } \\
\text { consumption-related ways for reducing material footprints can be based on similar } \\
\text { strategies as before, e.g., using less, sharing goods with other consumers, using instead of } \\
\text { owning, using infrastructure already existing, using less material-intensive materials, } \\
\text { products or energy modes, etc. }\end{array}$ \\
\hline $\begin{array}{l}\text { Central production- } \\
\text { related arguments, } \\
\text { examples, promising } \\
\text { practices }\end{array}$ & $\begin{array}{l}\text { - Accommodation in hotels or cottages can be developed less resource-intensive e.g., by } \\
\text { decreasing the amount of space required, by reducing the level of equipment, or by } \\
\text { increasing capacity use [98]. New collaborative consumption schemes like airbnb can even } \\
\text { reduce the need for additional hotels and second homes by making the use of existing } \\
\text { homes and second homes more efficient; } \\
\text { - As "other purposes" can contain any products or activities, production-related ways for } \\
\text { reducing material footprints can be based on similar strategies as in the examples mentioned } \\
\text { before, e.g., applying less resource-intensitve materials, products or energy modes, } \\
\text { designing goods and infrastructures for multi-purpose use and longevity, utilizing reused } \\
\text { components and recycled materials in production, etc. }\end{array}$ \\
\hline
\end{tabular}

\section{Conflicts of Interest}

The authors declare no conflict of interest.

\section{References}

1. Dittrich, M.; Giljum, S.; Lutter, S.; Polzin, C. Green Economies around the World? Implications of Re-source Use for Development and the Environment; Sustainable Europe Research Institute: Wien, Austria, 2012.

2. Bringezu, S.; Schütz, H.; Saurat, M.; Moll, S.; Acosta-Fernández, J.; Steger, S. Europe’s Resource Use. Basic Trends, Global and Sectoral Patterns and Environmental and Socioeconomic Impacts. In Sustainable Resource Management. Global Trends, Visions and Policies; Bringezu, S., Bleischwitz, R., Eds.; Greenleaf: Sheffield, UK, 2009; pp. 52-154.

3. Bringezu, S. Visions of a sustainable resource use. In Sustainable Resource Management. Global Trends, Visions and Policies; Bringezu, S., Bleischwitz, R., Eds.; Greenleaf: Sheffield, UK, 2009; pp. 155-215.

4. World Wide Fund for Nature (WWF). Living Planet Report 2012: Biodiversity, Biocapacity and Better Choices; Grooten, M., Almond, R., McLellan, R., Eds.; WWF International: Gland, Switzerland. 2012. Available online: http://awsassets.panda.org/downloads/1_lpr_2012_online_ full_size_single_pages_final_120516.pdf(accessed on 27 June 2014).

5. Spangenberg, H.J. Environmental space and the prism of sustainability: Frameworks for indicators measuring sustainable development. Ecol. Indic. 2002, 2, 295-309. 
6. Münz, R.; Reiterer, A.F. Overgrowded World: Population Explosion and International Migration, 1st ed.; Haus Publishing: London, UK, 2010.

7. Müller, H. Building a New World Order-Sustainable Policies for the Future, 1st ed.; Haus Publishing: London, UK, 2009.

8. Jäger, J. Our Planet: How Much More can Earth Take? 1st ed.; Haus Publishing: London, UK, 2009.

9. Rockström, J. A safe operating space for humanity. Nature 2009, 461, 472-475.

10. Smith, A. The Wealth of Nations: (A Modern Library E-Book); Random House Publishing Group: New York, NY, USA, 2000.

11. Defila, R.; Guilio, A.; Kaufmann-Hayoz, R. Wesen und Wege Nachhaltigen Konsums: Ergebnisse aus dem Themenschwerpunkt "Vom Wissen zum Handeln-Neue Wege zum Nachhaltigen Konsum”, 1st ed.; Oeconom Verlag: München, Germany, 2011. (In Germany)

12. Baedeker, C.; Bahn-Walkowiak, B.; Bleischwitz, R.; Kolberg, S.; Mont, O.; Stengel, O.; Stenbæk Hansen, M.; Welfens, M.J. Survey on Consumption Behaviour and Its Driving Forces; European Environment Agency, European Topic Centre on Resource and Waste Management: Copenhagen, Denmark, 2008.

13. Welfens, J.M.; Liedtke, C.; Nordmann, J. Sustainable consumption: Between unsustainable reality and people's willingsness to act. In Proceedings of the Knowledge Collaboration \& Learning for Sustainable Innovation ERSCP-EMSU conference, Delft, The Netherlands, 25-29 October 2010.

14. Mont, O. Concept paper for the International Task Force on Sustainable Lifestyles. In Proceedings of the Third International Expert Meeting on Sustainable Consumption and Production, Stockholm, Sweden, 26-29 June 2007.

15. Nissinen, A.; Grönroos, J.; Heiskanen, E.; Honkanen, A.; Katajajuuri, J.-M.; Kurppa, S.; Mäkinen, T.; Mäenpää, I.; Seppälä, J.; Timonen, P.; et al. Developing benchmarks for consumer-oriented life cycle assessment-based environmental information on products, services and consumption patterns. J. Clean. Prod. 2007, 15, 538-549.

16. Kuittinen, O.; Mokka, R.; Neuvonen, A.; Orjasniemi, M.; Ritola, M.; Wikholm, M. iFuture-The Diversity of Sustainable Lifestyles. In Report D7.3 People's Forum Workshop Summaries of the Project SPREAD Sustainable Lifestyles 2050; Demos Helsinki: Helsinki, Finland; Collaborating Centre on Sustainable Consumption and Production (CSCP): Wuppertal, Germany, 2012.

17. Liedtke, C.; Buhl, J.; Ameli, H. Microfoundations for sustainable growth with eco-intelligent product service-arrangements. Sustainability 2013, 5, 1141-1160.

18. Druckman, A.; Chitnis, M.; Sorell, S.; Jackson, T. Missing carbon reductions? Exploring rebound and backfire effects in UK households. Energy Policy 2011, 39, 3572-3581.

19. Höjer, M.; Mattsson, L. Determinism and backcasting in future studies. Futures 2000, 32, 613-634.

20. Neuvonen, A.; Kaskinen, T.; Leppänen, J.; Lähteenoja, S.; Mokka, R.; Ritola, M. Lifestyles backcasting as an agency-orientated method for creating sustainable futures. Futures 2014, 58, 66-76.

21. Scholz, R.W.; Lang, D.J.; Wiek, A.; Walter, A.I.; Stauffacher, M. Transdisciplinary case studies as a means of sustainability learning: Historical framework and theory. Int. J. Sustain. High. Educ. 2006, 7, 226-251. 
22. Rotmans, J.; Loorbach, D. Towards a better understanding of transitions and their governance-A systemic and reflexive approach. In Transitions to Sustainable Development-New Directions in the Study of Long Term Transformation Change, 1st ed.; Grin, J., Rotmans, J., Schot, J., Eds.; Routledge Chapman \& Hall: Loorbach, Germany, 2010; pp. 205-220.

23. Schneidewind, U. Ein institutionelles Reformprogramm zur Förderung transdisziplinärer Nachhaltigkeitsforschung. GAIA 2010, 19, 122-128. (In Germany)

24. Geels, F.W. The multi-level perspective on sustainability transitions: Responses to seven Transitions. Environ. Innov. Soc. Transit. 2011, 1, 24-40.

25. Talwar, S.; Wiek, A.; Robinson, J. User engagement in sustainability research. Sci. Public Policy 2011, 38, 379-390.

26. German Advisory Council on Global Change (WBGU). World in Transition. A Social Contract for Sustainability. In Flagship Report; WGBU: Berlin, Germany, 2011.

27. Lettenmeier, M.; Rohn, H.; Liedtke, C.; Schmidt-Bleek, F. Resource Productivity in 7 Steps. How to Develop Eco-innovative Products and Services and Improve Their Material Footprint; Wuppertal Spezial 41, Wuppertal Institute for Climate, Environment and Energy: Wuppertal, Germany, 2009.

28. Schmidt-Bleek, F. Wieviel Umwelt Braucht der Mensch? MIPS-Das Maß für Ökologisches Wirtschaften, 1st ed.; Birkhäuser: Berlin, Germany, 1993. (In Germany)

29. Lettenmeier, M.; Hirvilammi, T.; Laakso, S.; Lähteenoja, S.; Aalto, K. Material footprint of low-income households in Finland-Consequences for the sustainability debate. Sustainability 2012, 4, 1426-1447.

30. Ritthoff, M.; Rohn, H.; Liedtke, C. Calculating MIPS-Resource Productivity of Products and Services, 1st ed.; Wuppertal Spezial 27e, Wuppertal Institute for Climate, Environment and Energy: Wuppertal, Germany, 2002.

31. Schmidt-Bleek, F.; Bringezu, S.; Hinterberger, F.; Liedtke, C.; Spangenberg, J.H.; Stiller, H.; Welfens, M.J. MAIA Einführung in Die Material-Intensitäts-Analyse nach dem MIPS Konzept, 1st ed.; Birkhäuser: Basel, Switzerland, 1998.

32. Bringenzu, S.; Schütz, H.; Moll, S. Rationale for and interpretation of economy-wide materials flow analysis and derived indicators. J. Ind. Ecol. 2003, 7, 43-64.

33. Lähteenoja, S.; Lettenmeier, M.; Kotakorpi, E. The Ecological Rucksack of Households: Huge Differences, Huge Potential for Reduction? In Proceedings of the Sustainable Consumption and Production: Framework for Action: 2nd Conference of the Sustainable Consumption Research Exchange (SCORE!) Network (Refereed Sessions III-IV), Brussels, Belgium, 10-11 March 2008; Ken, T.G., Tukker, A., Vezzoli, C., Ceschin, F., Eds.; Flemish Institute for Technological Research NV (VITO): Mol, Belgium; The Netherlands Organization for Applied Scientific Research (TNO): Delft, The Netherlands, 2011; pp. 319-337.

34. Rohn, H.; Pastewski, N.; Lettenmeier, M.; Wiesen, K.; Bienge, K. Resource efficiency potential of selected technologies, products and strategies. Sci. Total Environ. 2014, 473-474, 32-35.

35. Sinivuori, P.; Saari, A. MIPS analysis of natural resource consumption in two university buildings. Build. Environ. 2006, 41, 657-668. 
36. Saari, A.; Lettenmeier, M.; Pusenius, K.; Hakkarainen, E. Influence of vehicle type and road category on the natural resource consumption in road transport. Transp. Res. Part D 2007, 12, $23-32$.

37. Watson, D.; Acosta Fernández, J.; Wittmer, D.; Gravgård Pedersen, O. Environmental Presssures from European Consumption and Production. A study in integrated environmental and economic analysis. In EEA Technical Report; Publications Office of the European Union: Luxembourg, 2013; Volume 2.

38. Acosta Fernández, J. Durch den Konsum der Privaten Haushalte Direkt und Indirekt Induzierter TMR, Deutschland; Wuppertal Institute: Wuppertal, Germany, 2005. (In Germany)

39. Kotakorpi, E.; Lähteenoja, S.; Lettenmeier, M. Household MIPS. Natural resource consumption of Finnish households and its reduction. In The Finnish Environment; Ministry of the Environment: Helsinki, Finland, 2008; p. 43.

40. Mäenpää, I.; Juutinen, A. Materials Flows in Finland: Resource Use in a Small Open Economy. J. Ind. Ecol. 2001, 5, 33-48.

41. Mäenpää, I. Kansantalouden ainevirtatilinpito. Laskentamenetelmät ja käsitteet. Suomen ainetaseet (National material flow accounting. Calculation methods and glossary. Finnish material balance); Edita Prima Oy: Helsinki, Finland, 1999. (In Finnish)

42. Mancini, L.; Lettenmeier, M.; Rohn, H.; Liedtke, C. Application of the MIPS Method for assessing the sustainability of production-consumption systems of food. J. Econ. Behav. Organ. 2011, 81, 779-793.

43. Rohn, H.; Lettenmeier, M.; Pastewski, N. Ressourceneffizienz-Potenziale von Technologien, Produkten und Strategien, 1st ed.; Fraunhofer Verlag: Stuttgart, Germany, 2013. (In Germany)

44. Geibler, J.; Rohn, H.; Schnabel, F.; Meier, J.; Wiesen, K.; Ziema, E.; Pastewski, N.; Lettenmeier, M.; Resource Efficiency Atlas. An International Perspective on Technologies and Products with Resource Efficiency Potential. In Wuppertal Spezial; Wuppertal Institute: Wuppertal, Germany, 2011; Volume 44.

45. Lähteenoja, S.; Lettenmeier, M.; Kauppinen, T.; Luoto, K.; Moisio, T.; Salo, M.; Tamminen, P.; Veuro, S. Natural Resource Consumption Caused by Finnish Households. In Proceedings of the Nordic Consumer Policy Research Conference, Helsinki, Finland, 3-5 October 2007; Nordic Council of Ministers, Ministry of Trade and Industry, National Consumer Research Centre: Helsinki, Finland, 2007.

46. Laakso, S. Onko Elämä Perusturvan Varassa Kestävää? Ympäristövara Ekologisesti ja Sosiaalisesti Kestävän Kulutuksen Tarkastelussa (Is Life on Basic Social Security Sustainable? Environmental Space as a Framework for Studying Ecologically and Socially Sustainable Consumption. In Finnish). Master's Thesis, University of Helsinki, Helsinki, Finland, December 2011.

47. Tukker, A.; Cohen, M.J.; Hubacek, K.; Mont, O. The impacts of household consumption and options for change. J. Ind. Ecol. 2010, 14, 13-30.

48. Seppälä, J.; Mäenpää, I.; Koskela, S.; Mattila, T.; Nissinen, A.; Katajajuuri, J.; Härmä, T.; Korhonen, M.; Saarinen, M.; Virtanen, Y. An assessment of greenhouse gas emissions and material flows caused by the Finnish economy using the ENVIMAT model. J. Clean. Prod. 2011, 19, 1833-1841. 
49. Tukker, A.; Huppes, G.; Guinée, J.; Heijungs, R.; De Koning, A.; Oers, L.; Suh, S.; Geerken, T.; Holderbecke, M.; Jansen, B.; Nielsen, P. Environmental Impact of Products (EIPRO)—Analysis of the life cycle environmental impacts related to the final consumption of the EU-25. Main report. IPTS/ESTO project. In Technical Report EUR 22284 EN; European Commission, Joint Research Centre (DG JRC), Institute for Prospective Technological Studies: Seville, Spain, 2006.

50. Lettenmeier, M.; Lähteenoja, S.; Hirvilammi, T.; Aalto, K.; Laakso, S. Maximum and Minimum Consumption-A Two-Dimensional Approach in Defining a Decent Lifestyle. In Proceedings of Trends and Future of Sustainable Development, Tampere, Finland, 9-10 June 2011; Lakkala, H., Vehmas, J., Eds.; FFRC eBooks 15/2011; Finland Futures Research Centre, University of Turku: Turku, Finland, 2011; pp. 202-212.

51. Lehtinen, A.-R.; Varjonen, J.; Raijas, A.; Aalto, K. What Is the Cost of Living? Reference Budgets or a Decent Minimum Standard of Living; In National Consumer Research Centre Working papers 132/2011; National Consumer Research Centre: Helsinki, Finland, 2011.

52. Groezinger, R.; Verbree, R.; Hicks, C.; Ritola, M. Scenarios for sustainable lifestyles. Pathways toward a positive future, Ökom: Ökologisches Wirtschaften, Munich, 2013; Jg. 28, No. 3, pp. 41-46.

53. Nurmela, J.; Mäenpää, I. Kulutettu Euro Haukkaa 1,5 Kiloa Luontoa (One Euro Consumed Requires 1.5 Kilos of Nature. In Finnish), Tieto\&trendit 8/2009; Statistics Finland: Helsinki, Finland, 2009.

54. Ayres, R.U.; Knees, A.V. Production, consumption, and externalities. Am. Econ. Rev. 1969, 59, 282-297.

55. Baccini, P.; Brunner P.H. Metabolism of the Anthroposphere, 1st ed.; Springer-Verlag: Berlin, Germany, 1991.

56. Schmidt-Bleek, F. The Earth: Natural Resources and Human Intervention, 1st ed.; Haus Publishing: London, UK, 2009.

57. Ekins, P.; Meyer, B.; Schmidt-Bleek, F. Reducing Resource Consumption. A Proposal for Global Resource and Environmental Policy. In Discussion Paper 5; Gesellschaft für Wirtschaftliche Strukturforschung mbH: Osnabrück, Germany, 2009.

58. Bringenzu, S.; Schütz H. Ziele und Indikatoren für die Umsetzung von ProgRess; Ressourcen Politik Arbeitspapier, Arbeitspapier AS 1.2/1.3; Wuppertal Institute: Wuppertal, Germany, 2013; p. 35. (In Germany)

59. Liedtke, C.; Lettenmeier, M.; Buhl, J.; Teubler, J.; Greiff, K.; Schipperges, M. Discussing the usefulness of statistics for assessing the resource use of households. In Proceedings of the World Resources Forum 2013, Davos, Switzerland, 6-9 October 2013.

60. Bringezu, S. Key elements for Economy-wide Sustainable Resource Management (1). Ann. Mines Ser. Responsab. Environ. 2011, 61, 78-87.

61. Lähteenoja, S.; Lettenmeier, M.; Saari, A. Transport MIPS. Natural Resource Consumption of the Finnish Transport System. In The Finnish Environment; Ministry of the Environment: Helsinki, Finland, 2006; Volume 820 
62. Leppänen, J.; Neuvonen, A.; Ritola, M.; Ahola, I.; Hirvonen, S.; Hyötyläinen, M.; Kaskinen, T.; Kauppinen, T.; Kuittinen, O.; Kärki, K.; et al. Scenarios for Sustainable Lifestyles 2050: From Global Champions to Local Loops. In Report D4.1 Future Scenarios for New European Social Models with Visualisations of the Project SPREAD Sustainable Lifestyles 2050; Demos Helsinki: Helsinki, Finland; Collaborating Centre on Sustainable Consumption and Production (CSCP): Wuppertal, Germany, 2012.

63. Power, K.; Mont, O. Dispelling the myths about consumption behaviour. In Proceedings of the ERSCP-EMSU Conference "Knowledge Collaboration \& Learning for Sustainable Innovation", Delft, The Netherlands, 25-29 October 2010.

64. Kaskinen, T.; Kuittinen, O.; Neuvonen, A.; Mokka, R. Gatekeepers changing consumers' behaviour in energy consumption. In Future of the Consumer Society, Proceedings of the Conference Future of the Consumer Society, Tampere, Finland, 28-29 May 2009; Koskela, M., Vinnari, M., Eds.; FFRC eBooks 7/2009. Finland Futures Research Centre, Turku School of Ecnomics: Turku, Finland, 2009.

65. Luoto, K.; Lähteenoja, S.; Lettenmeier, M. Liikunta MIPS-Liikuntaharrastusten Luonnonvarojen Kulutus (Exercise MIPS-Consumption of Natural Resources in Exercise); Publications of the National Consumer Research Centre Series 4; National Consumer Research Centre: Helsinki, Finland, 2008. (In Finnish)

66. Veuro, S.; Satu, L.; Lettenmeier, M. Vapaa-aikaMIPS_Vapaa-ajan Vieton Luonnonvarojen Kulutus (Hobby MIPS - Consumption of Natural Resources in Leisure Time); Publications of the National Consumer Research Centre Series 5; National Consumer Research Centre: Helsinki, Finland, 2008. (In Finnish)

67. Handy, S.L.; Clifton, J.K. Local shopping as a strategy for reducing automobile travel. Transportation 2001, 28, 317-346.

68. Dombois, O.T.; Braun-Fahrländer, C.; Martin-Diener, E. Comparison of adult physical activity levels in three Swiss alpine communities with varying access to motorized transportation. Health Place 2007, 13, 757-766.

69. Lettenmeier, M.; Autio, S.; Jänis, R. Project-based learning on life-cycle management-A case study using material flow analysis. In Proceedings of the World Resources Forum 2013, Davos, Switzerland, 6-9 October 2013.

70. Türk, V.; Kuhndt, M.; Alakeson, V.; Aldrich, T.; Geibler, J. The Environmental and Social Impacts of Ebanking: A Case Study with Barclays PLC, Final Report; Digital Europe, Wuppertal Institute: Wuppertal, Germany, 2003.

71. Rohn, H.; Pastewski, N.; Lettenmeier, M. Resource efficiency of selected technologies, products and strategies: Executive Summary. In Resource Efficiency Paper 1/7; Wuppertal Institute for Climate, Environment and Energy: Wuppertal, Germany, 2010.

72. Leismann, K.; Schmitt, M.; Rohn, H.; Baedeker, C.; Collaborative Consumption. Towards a resource-saving consumption culture. Resources 2013, 2, 184-203. 
73. Lettenmeier, M.; Göbel, C.; Liedtke, C.; Rohn, H.; Teitscheid, P. Material Footprint of a Sustainable Nutrition System in 2050-Need for Dynamic Innovations in Production, Consumption and Politics. In Proceedings of the 6th International European Forum (Igls-Forum) on System Dynamics and Innovation in Food Networks (PFSD 2012), Innsbruck, Austria, 13-17 February 2012; pp. 484-598.

74. Kaskinen, T. Peloton Magazine, 1st ed.; Demos Helsinki: Helsinki, Finland, 2011.

75. Rohn, H.; Lettenmeier, M. Reducing the Material Footprint of Meals. In Proceedings of the World Resources Forum 2013, Davos, Switzerland, 6-9 October 2013.

76. Lettenmeier, M.; Rohn, H. Ökologische Bewertung der Warenverluste: Ressourcennutzung und Umweltbelastung in der Vorkette von Lebensmittelabfällen. In iSuN, Fachhochschule Münster, Münster, Germany (ed.): Verringerung von Lebensmittelabfällen-Identifikation von Ursachen und Handlungsoptionen in Nordrhein-Westfalen; University of Applied Sciences Münster: Münster, Germany, pp. 98-107. (In Germany)

77. Bates, A.; Hemenway, T. From agriculture to permaculture. In State of the World 2010: Transforming Cultures from Consumerism to Sustainability; Starke, L., Mastny, L., The Worldwatch Institute, WW Norton: New York, NY, USA, 2010; pp. 47-53.

78. Mancini, L. Food Habits and Environmental Impact: An Assessment of the Natural Resource Demand in Three Agri-Food Chains. Ph.D. Dissertation, Faculty of Agriculture, Polytechnic University of Marche, Ancona, Italy, 2011.

79. iSuN, Ed. Verringerung von Lebensmittelabfällen-Identifikation von Ursachen und Handlungsoptionen in Nordrhein-Westfalen; Fachhochschule Münster: Münster, Germany, 2012. (In Germany)

80. Backhaus, J.; Breukers, S.; Mont, O.; Paukovic, M.; Mourik, R. Sustainable lifestyles: Today’s facts \& tomorrow's trends. In D1.1 Sustainable Lifestyles Baseline Report. European Commission, SPREAD Sustainable Lifestyles 2050; ECN: Amsterdam, The Netherlands; Collaborating Centre on Sustainable Consumption and Production (CSCP): Wuppertal, Germany, 2012.

81. Grinewitschus, V.; Lovrić, T.; Rumler N. Influence of user behavior and home automation on energy consumption. In Proceedings of the 7th International Conference on Energy Efficiency in Domestic Appliances and Lighting (EEDAL'13), Coimbra, Portugal, 11-13 September 2013.

82. Directive 2010/31/EU of the European Parliament and of the Council of 19 May 2010 on the energy performance of buildings. Off. J. Eur. Union 2010, 53, 13-35.

83. Cree Homepage. Available online: http://www.cree.at/en/ (accessed on 18 November 2012).

84. Fechner, J.; Lipp, B.; Lechner, R. Bewertete Realisierungsbeispiele im "Haus der Zukunft". Herausgeber: bmvit, ÖKOinFORM Folder 6. Available online: http://www.hausderzukunft.at/ results.html/id1719 (accessed on 14 May 2013.)

85. Nieminen, A.; Lettenmeier, M.; Saari, A. Luonnonvarojen Kulutus Suomen LentoliikenteessäLentoMIPS. (Natural Resource Consumption in Finnish Air Transport_Flying MIPS); Publications of the Ministry of Transport and Communications Series 57; The Ministry of Transport and Communications: Helsinki, Finland, 2005. (In Finnish)

86. Wiesen, K.; Teubler, J.; Rohn, H. Resource use of two wind farms in the German North Sea-The examples of Alpha Ventus and Bard Offshore I. Resources 2013, 2, 504-516. 
87. Samus, T.; Lang, B.; Rohn, H. Assessing the natural resource use and the resource efficiency potential of the Desertec concept. Sol. Energy 2013, 87, 176-183.

88. Schmidt-Bleek, F., Ed. Der Ökologische Rucksack. Wirtschaft für eine Zukunft mit Zukunft, 1st ed; Hirzel: Stuttgart, Germany, 2004. (In Germany)

89. Leismann, K.; Schmitt, M.; Rohn, H.; Baedeker, C. Nutzen statt Besitzen. Auf dem Weg zu einer ressourcenschonenden Konsumkultur. In Schriften zur Ökologie, Band 27; Heinrich Böll Stiftung: Berlin, Germany, 2010. (In Germany)

90. Autio, S.; Lettenmeier, M. Ekotehokkuus-Business as Future. Yrityksen ekoteho-opas. (Eco-efficiency guide for companies. In Finnish.) In Dipoli-raportit/Dipoli-reports C, ympäristökoulutus; TKK Dipoli: Espoo, Finland, 2002.

91. Salo, V.; Lettenmeier, M. Sähkölaite MIPS. Käyttöiän ja energiatehokkuuden vaikutus sähkölaitteiden aiheuttamaan materiaalipanokseen (MIPS of electric and electronic equipment. Influence of life-time and energy efficiency on the material input of electric and electronic equipment); Helsingin Reuse Centre: Helsinki, Finland, 2006. (In Finnish)

92. Material Intensity Factors. Available online: http://wupperinst.org/en/info/details/wi/a/s/ad/365/ (accessed on 22 April 2013).

93. Institut für Umweltkommunikation (INFU); Wuppertal Institut für Klima, Umwelt, Energie GmbH (WI); Institute for Advanced Sustainability Studies (IASS); Bundesministerium für Bildung und Forschung; Projektgruppe Wissenschaftsjahr Zukunftsprojekt Erde; Ed. Die Rohstoff-Expedition: Entdecke, was in (d)einem Handy Steckt! Lern- und Arbeitsmaterial: Bonn, Germany, 2012. Available online: http://www.die-rohstoff-expedition.de (accessed on 27 June 2014).

94. Buhl, J.; Greiff, K.; Lettenmeier, M.; Liedtke, C.; Meyer, M.; Steger, S.; Teubler, J. Global Nachhaltige Materielle Wohlstandsniveaus-Analyse und Veranschaulichung Global Nachhaltiger Materieller Versorgungsgrade auf der Ebene von Haushalten, Intermediate report April 2013; Gws: Osnabrück, Germany; Wuppertal Institute: Wuppertal, Germany, 2013. (In Germany)

95. Ornetzeder, M.; Hertwich, E.G.; Hubacek, K.; Korytarovad, K.; Haas, W. The environmental effect of car-free housing: A case in Vienna. Ecol. Econ. 2008, 65, 516-530.

96. Talja, S.; Lettenmeier, M.; Saari, A. Luonnonvarojen Kulutus Paikallisessa LiikenteessäMenetelmänä MIPS (Natural Resource Consumption of Local Transport according to the MIPS Concept. In Finnish); Publication of the Ministry of Transport and Communications Series 14; The Ministry of Transport and Communications: Helsinki, Finland, 2006.

97. Partanen, R.; Paloheimo, H.; Waris, H. Suomi Öljyn Jälkeen (Finland after oil); Into Kustannus: Helsinki, Finland, 2013. (In Finnish)

98. Salo, M.; Lähteenoja, S.; Lettenmeier, M. Matkailu MIPS-Matkailun luonnonvarojen kulutus (Tourism MIPS - Consumption of natural resources by tourism). Publications of the Ministry of Employment and the Economy Series 8; The Ministry of Employment and the Economy: Helsinki, Finland, 2008. (In Finnish)

(C) 2014 by the authors; licensee MDPI, Basel, Switzerland. This article is an open access article distributed under the terms and conditions of the Creative Commons Attribution license (http://creativecommons.org/licenses/by/3.0/). 